NBER WORKING PAPER SERIES

HOW TEACHER TURNOVER HARMS STUDENT ACHIEVEMENT

\author{
Matthew Ronfeldt \\ Hamilton Lankford \\ Susanna Loeb \\ James Wyckoff \\ Working Paper 17176 \\ http://www.nber.org/papers/w17176
}

\author{
NATIONAL BUREAU OF ECONOMIC RESEARCH \\ 1050 Massachusetts Avenue \\ Cambridge, MA 02138 \\ June 2011
}

The views expressed herein are those of the authors and do not necessarily reflect the views of the National Bureau of Economic Research.

NBER working papers are circulated for discussion and comment purposes. They have not been peerreviewed or been subject to the review by the NBER Board of Directors that accompanies official NBER publications.

(C) 2011 by Matthew Ronfeldt, Hamilton Lankford, Susanna Loeb, and James Wyckoff. All rights reserved. Short sections of text, not to exceed two paragraphs, may be quoted without explicit permission provided that full credit, including $(\odot)$ notice, is given to the source. 
How Teacher Turnover Harms Student Achievement

Matthew Ronfeldt, Hamilton Lankford, Susanna Loeb, and James Wyckoff

NBER Working Paper No. 17176

June 2011

JEL No. I21

\section{ABSTRACT}

Researchers and policymakers often assume that teacher turnover harms student achievement, but recent evidence calls into question this assumption. Using a unique identification strategy that employs grade-level turnover and two classes of fixed-effects models, this study estimates the effects of teacher turnover on over 600,000 New York City 4th and 5th grade student observations over 5 years. The results indicate that students in grade-levels with higher turnover score lower in both ELA and math and that this effect is particularly strong in schools with more low-performing and black students. Moreover, the results suggest that there is a disruptive effect of turnover beyond changing the composition in teacher quality.

Matthew Ronfeldt University of Michigan

School of Education

ronfeldt@stanford.edu

Hamilton Lankford

School of Education, ED 317

University at Albany

State University of New York

Albany, NY 12222

hamp@albany.edu

\author{
Susanna Loeb \\ 524 CERAS, 520 Galvez Mall \\ Stanford University \\ Stanford, CA 94305 \\ and NBER \\ sloeb@stanford.edu \\ James Wyckoff \\ Curry School of Education \\ University of Virginia \\ P.O. Box 400277 \\ Charlottesville, VA 22904-4277 \\ wyckoff@virginia.edu
}




\title{
How teacher turnover harms student achievement
}

\author{
Matthew Ronfeldt, Hamp Lankford, Susanna Loeb, and Jim Wyckoff
}

\section{INTRODUCTION}

Teacher turnover rates are high, particularly in schools serving low-income, non-white and low-achieving student populations. Nationally, about 30 percent of new teachers leave the profession after five years, and the turnover rate is 50 percent higher in high-poverty schools as compared to more affluent ones (Ingersoll, 2001). Teacher turnover rates also tend to be higher in urban and lower-performing schools (Hanushek, Kain, and Rivkin, 1999). As an example, in New York City approximately 18 percent of teachers leave their school each year.

Researchers and policy makers often assume that teacher turnover harms student learning. There are many reasons to think it would, as institutional memory is lost and resources are spent on the hiring process. Yet, there exists little empirical evidence for a direct effect of teacher turnover on student achievement (Guin, 2004). Moreover, the organizational management literature has demonstrated that some amount of turnover may in fact be beneficial to institutions and individuals. Institutional turnover can, for example, result in better person-job matches and infusion of new ideas into organizations (Abelson \& Baysinger, 1984). These benefits of turnover can be enhanced if it is the less effective employees who leave.

A growing body of evidence indicates that teachers who produce higher student achievement gains are at least as likely, and sometimes more likely, to stay in schools than their less effective peers (Boyd et al, 2010; Goldhaber, D., Gross, B., and Player, D., 2007; Hanushek \& Rivkin, 2010). For example, Boyd et al. (2010) studied data on teachers' applications for transfer to uncover which teachers are more likely to want to transfer from NYC schools. They discovered that teachers who produced higher achievement gains and those with more experience were less likely to 
apply for transfer. ${ }^{1}$ This reduced interest in moving held true even for teachers in the lowestperforming schools. Similarly, Hanushek and Rivkin (2010) found that, in Texas, those who left a given school tended to be less effective than those who stayed. Contrary to common assumptions, the relative effectiveness of stayers as compared to leavers was actually highest in schools with more low-achieving and black students. Because neither Boyd et al. (2010) nor Hanushek and Rivkin (2010) directly tested whether the teachers who filled vacancies in a given school were more effective on average than those they replaced, it is difficult to draw conclusions about the overall impact of turnover. However, Hanushek and Rivkin did simulate the impact were only "rookie" teachers to replace exiting ones, and found no overall effect of turnover on student achievement.

The results of the Hanushek and Rivkin (2010) simulation are an important challenge to the commonly held assumption that teacher turnover harms student achievement, especially that of lowperforming, poor, and minority students. However, their findings have important limitations, even aside from being simulated, rather than observed, effects of new hires. Namely, the results assume that the only lever by which teacher turnover harms or helps student achievement is by adjusting the average effectiveness of individual teachers on the school's faculty. Students are thought to benefit when they get teachers who are more effective than the ones that left the school. But turnover may impact student achievement beyond the relative effectiveness of those who stay as compared to those who leave.

When teachers leave schools, for example, previously held relationships and collaborations are lost, and new ones form. Bryk \& Schneider (2002) argue that the quality of relationships (trust) between teachers, and between teachers and students, is related to student achievement. To the degree that turnover disrupts the formation or maintenance of these relationships, it may also harm

\footnotetext{
${ }^{1}$ On the other hand, they found that teachers with better pre-service qualifications (LAST scores, competitiveness of undergraduate institution) were more likely to apply for transfer.
} 
student achievement. On the other hand, turnover may result in the infusion of new ideas into the organization which might help raise student achievement.

Although it is important to consider and study the separate mechanisms by which turnover may impact student achievement - relational trust, infusion of new ideas, changes in average teacher effectiveness - we still know very little about the overall effect of attrition on students. Guin (2004) studied 66 elementary schools in a large urban district to look at relationships between school-level turnover and the proportion of students meeting standards on statewide assessments in reading and math. Pearson correlations were significant and negative, demonstrating that schools with higher turnover also had lower achievement. However, the findings are clearly not causal as low achievement may cause teachers to leave, teachers leaving may cause low achievement, or a third factor (e.g. poverty, crime, or poor school leadership) may simultaneously cause both low achievement and higher turnover.

Using a unique identification strategy, and two classes of fixed-effects regression models, this study presents the cleanest estimates to date of a direct effect of teacher turnover on student achievement. Three research questions guide the investigation: What is the average effect of teacher turnover on student achievement? Are the effects different for different kinds of schools? What explains the relationship between teacher turnover and student achievement? The paper proceeds as follows. We first describe the data and methodological approach. We then present the results and conclude with a discussion of the implications of the findings.

\section{DATA}

This study draws on extensive administrative data from the New York City Department of Education and the New York State Education Department. Analyses focus on approximately 625,000 observations of $4^{\text {th }}$ and $5^{\text {th }}$ grade students across all New York City elementary schools over 
five academic years (2000-2002; 2004-2007). ${ }^{2}$ We were able to link student test scores in math and ELA to student, class, school, and teacher characteristics.

Table 1 describes student, teacher, and school-by-grade characteristics. About 70 percent of students in $4^{\text {th }}$ and $5^{\text {th }}$ grades in NYC were either black or Hispanic. Over one-third of students had a home language other than English, and 61 percent were on free or reduced priced lunch. The $4^{\text {th }}$ and $5^{\text {th }}$ grade teachers in the district had, on average, six years of experience. Approximately 2 percent of students had been suspended in the previous year, while 9 percent had switched schools since the prior year. Finally, students were absent for an average of approximately 11 days in the previous year.

On average, 82 percent of teachers each year had stayed in the same school from the prior year (stayers). Approximately four percent of $4^{\text {th }}$ and $5^{\text {th }}$ grade teachers had transferred schools (movers), while 12 percent were first year teachers. Each $4^{\text {th }}$ and $5^{\text {th }}$ grade within each NYC school had, on average, six teachers, with a range from one to as many as 22 teachers. Figure A plots the distribution of teachers per grade in the sample schools.

Our identification strategy requires measuring school-by-grade level turnover in each year. Such measurement is not entirely straightforward. To illustrate, imagine a $4^{\text {th }}$ grade within School A that had six teachers in year 0 . Due to increasing enrollments, in year 1 there were seven $4^{\text {th }}$ grade teachers. Of these, five were stayers, one a mover, and one a first year teacher. Teacher turnover could be estimated as the proportion of year 0 teachers that were no longer in the $4^{\text {th }}$ grade in School A in year 1 (1/6=16.7 percent). On the other hand, turnover could be measured as the proportion of teachers that were new to the school-by-grade in year 1 -- either first year teachers or movers (2/7=28.6 percent). The first measure -- "lagged attrition" -- defines turnover as the proportion of

\footnotetext{
${ }^{2}$ Due to peculiarities in the NYC administrative data collected in 2002-2003, we were unable to identify the grade levels of all teachers in NYC. Since our analyses depend upon grade-level information across the district, we focused our study on the years we had data prior to and following the 2002-2003 academic year.
} 
teachers in a given grade level in year $\mathrm{t}-1$ who left the school by year $\mathrm{t}$. The second measure -"proportion new" -- defines turnover as the proportion of teachers in a given grade level who are new (movers or first year teachers) to the school in year $\mathrm{t}$. We used both measures in all analyses to test whether results were robust across them; the distributions for lagged attrition can be seen in Figure B and for proportion new in Figure C. The measures have similarly shaped distributions, bell shaped with a right skew.

The average teacher turnover rate in each grade in each school in each year was similar for both of the measures we developed: 0.20 for the lagged attrition measure and 0.21 for the proportion new measure. Thus, each year, approximately one out of every five $4^{\text {th }}$ and $5^{\text {th }}$ grade teachers in NYC left or came to a given grade level in a given school. Lagged attrition could result from teachers leaving the profession altogether or transferring to another school. This measure does not include the transfer of teachers from one grade to another within the same school. We chose not to include this behavior because, in such cases, the expertise of teachers would remain within the same school. ${ }^{3}$ More than one-third of school-by-grades experienced no teacher turnover each year (between 36 percent and 37 percent). On the other hand, between two and three percent of $4^{\text {th }}$ and $5^{\text {th }}$ grade level teams had turnover rates of 100 percent each year. ${ }^{4}$

\section{METHODS}

As described above, our analyses are driven by three questions: What is the average effect of teacher turnover on student achievement? Are the effects different for different kinds of schools? And what explains the relationship between teacher turnover and student achievement?

\footnotetext{
${ }^{3}$ We also ran models that included indicators for whether teachers switched grade levels. Results were similar suggesting the grade-level switching does not account for the effects of grade-level turnover on student achievement.

${ }^{4}$ We use many classroom and school-level characteristics as controls in the regression models described below. Appendix Table 1 describes these variables used as school and classroom controls in analyses.
} 
What is the average effect of teacher turnover on student achievement? Typically teacher turnover is measured at the school level. However, high turnover rates in the $6^{\text {th }}$ grade may have little impact on incoming $4^{\text {th }}$ grade students, especially when the 4 th grade level team stays intact. To get a more precise estimate of the effects of turnover, this study examines turnover at the school-bygrade-by-year level, rather than at the school or school-by-year level. Another benefit of examining school-by-grade-by-year level turnover is that we can adjust for school-by-grade or school-by-year level factors that could influence both student achievement and turnover. For example, if the school's principal leaves the transition could simultaneously affect both turnover and achievement. If we do not measure this effect then our results would be biased, showing an association between turnover and achievement even if no causal relationship exists. Focusing on school-by-grade-byyear level turnover allows us to adjust for school-by-year level factors, both observed and not observed.

For each analysis we use two different estimation strategies to study the effects of school-by grade level teacher turnover on student achievement. First, we use regression models with schoolby-grade fixed effects to leverage variation in turnover across years within the same grade level and school. This allows us to examine whether students within the same grade level and within the same school had better or worse test score gains in a given year, as compared to other years when teacher turnover was at different rates. All models control for prior student achievement, but we also control for other student, class, school, grade, and teacher characteristics depending on the analysis. Equation 1 summarizes the regression model used for these analyses:

$$
A_{\text {iggy }}=\beta_{0}+\beta_{1} A_{i t g s(y-1)}+\beta_{2} \text { Other } A_{i t g s(y-1)}+\beta_{3} X_{i t g s y}+\beta_{4} C_{t g s y}+\beta_{5} S_{s y}+\phi_{y}+v_{g s}+\beta_{6} T_{g s y}+\varepsilon_{i t g s y}
$$


The test performance of individual, $i$, with teacher, $t$, in grade, $g$, in school, $s$, in time, $y$, is a function of his/her test performance in that subject, $A$, and the other subject, $A O t h e r$, in the prior year, student background characteristics, $X$, time varying classroom characteristics, $C$, time varying school characteristics, $S$, year fixed effects, $\phi$, grade-by-school fixed effects, $v$, the grade-by-school-by-year turnover measure, $T$, and an error term, $\varepsilon$.

In our second method of analyses, we use school-by-year, instead of school-by-grade, fixed effects to capitalize on turnover variation across grades within the same year and school. The advantage of the second method is that year-to-year variations cannot explain observed effects; however, the disadvantage is that it assumes turnover rates have comparable effects on student achievement at different grade levels. All models control for prior student achievement, but we also control for other student, class, school, grade, and teacher characteristics depending on the analysis. Equation 2 describes the second method of analysis:

$A_{i t g y}=\beta_{0}+\beta_{1} A_{i t g s(y-1)}+\beta_{2}$ Other $A_{i t g s(y-1)}+\beta_{3} X_{i t g s y}+\beta_{4} C_{\text {tgsy }}+\beta_{5} S_{s y}+\phi_{g}+v_{s y}+\beta_{6} T_{g s y}+\varepsilon_{i t g s y}$

The test performance of individual, $i$, with teacher, $t$, in grade, $g$, in school, $s$, in time, $y$, is a function of his/her test performance in that subject, $A$, and the other subject, AOther, in the prior year, student background characteristics, $X$, time varying classroom characteristics, $C$, time varying school characteristics, $S$, grade fixed effects, $\phi$, year-by-school fixed effects, $v$, the grade-by-school-by-year turnover measure, $T$, and an error term, $\varepsilon$.

What explains the relationship between teacher turnover and student achievement? There are multiple potential mechanisms leading to the effects of turnover that we estimate in Equations 1 and 2. For example, turnover may affect achievement because the teachers who replaced those who 
left were either more or less effective (we refer to this as the "compositional" effect). Alternatively, even where the arriving and leaving teachers were equally effective, the turnover itself may cause a broader disruption that impacts all students, even students of teachers who did not transition (we refer to this as the "disruption" effect).

To examine the effect of differentially effective teachers we add teacher experience indictor variables to see whether any observed turnover effects are driven by changes in experience of the teachers; we then add an indicator variable for being a new teacher in the school to see whether any observed effects are driven by teachers who are new to the school being worse. We also run separately models that control for teachers' average prior value-added to see if the effect is driven by changes in the effectiveness of teachers leaving and entering grade level teams.

The drawback to this approach of controlling for measured teacher characteristics is that there may be unmeasured characteristics of teachers that differ between new and remaining teachers that affect student performance. In order to further distinguish the disruption effect from the compositional effect, we rerun our analyses but only for students who had teachers who were in the same grade-by-school group in the prior year (i.e. students of "stayers"). If there were no disruption effects, we should not see an effect of turnover for students in this group. We run these analyses for the models in both Equation 1 and Equation 2.

Another approach we used to dissect the relationship between teacher turnover and student achievement was to look at whether the relationship varied in different kinds of schools. For example, during the period of this study, NYC opened a number of new schools, many of which were small and expanding. To see whether our results were driven by these new schools we ran models separately for large versus small schools, and for new versus old schools. Additionally, many have suggested that the effects of turnover will be most harmful in schools with more lowperforming and minority students, especially given that the turnover rates tend to be higher in these 
kinds of settings. To test whether the effects of turnover are different in schools with these populations of students we ran models separately in low versus high performing schools, and in low versus high percentage black schools.

\section{RESULTS}

\section{What is the average effect of teacher turnover on student achievement?}

Table 2 describes the results for our estimates of the effects of teacher turnover on student achievement when comparing students within the same grade within the same school but in different years (grade-by-school fixed effects models). Model 1 includes year fixed effects as well as school-by-grade fixed effects, while Model 2 adds in student, class, and school-level controls. ${ }^{5}$ Note that each estimate in Table 2 comes from a separate estimation. The estimations vary in their outcome variable (math or ELA) and in their measure of turnover (proportion of new teachers or lagged attrition). The estimated coefficients are negative and significant for test scores in both ELA and math and for all model specifications, suggesting that the students of teachers in the same grade level team in the same school do worse in years where teacher turnover rates are higher, as compared to years with less teacher turnover. Student math scores are six to seven percent of a standard deviation lower in years when there was 100 percent turnover as compared to years where there was no turnover at all. Effect sizes are somewhat smaller in ELA than in math, estimated at between three and six percent of a standard deviation decrease.

Across models, estimates were somewhat larger when signaling teacher turnover using the proportion of new teachers to a grade level team as compared to the proportion of teachers who left a grade level team in the prior year. We are not certain why this is the case, but we suspect it may be the result of differences in the sensitivity of measures to variation in turnover across years where

5 Table 1 describes the student controls used in these models; Appendix Table 1 describes the classroom and school controls. 
there was growth or decline in the number of teachers within a particular grade-by-school. To illustrate, Table 3 includes three different scenarios - when there is an increase in the number of teachers in a hypothetical $4^{\text {th }}$ grade in a hypothetical School A; when there is a decline in the number of teachers; and when the number of teachers stays the same. As the table demonstrates, the lagged attrition measure may be less sensitive to changes caused by turnover in growth years. On the other hand, in decline years, the proportion new measure may fail to detect changes due to turnover. In the five-year period we studied in NYC, we found that grade-by-school teams experienced average increases in faculty size in grades 4 and $5 ;^{6}$ this average growth may explain why the lagged attrition estimates were relatively lower.

Table 4 describes the estimates for models using school-by-year fixed effects instead of school-by-grade fixed effects. Looking across models and measures, the results are similar. The consistently negative and statistically significant estimates again suggest that teacher turnover harms student achievement. More specifically, the results indicate that within the same school and within the same year, students in grade levels that experience100 percent turnover had lower test scores by four to seven percent of a standard deviation in math and by three to seven percent of a standard deviation in ELA, as compared to grade levels with no turnover at all. As with models using schoolby-grade fixed effects, estimates were consistently lower when signaling turnover with lagged attrition as compared to the proportion of new faculty.

To get a better sense about the magnitude of the effects, we examined the effects at different quartiles of teacher turnover. Table 5 describes grade-by-school-by-year-level characteristics at different quartiles of teacher turnover. The bottom quartile (least turnover) is comprised of only grade levels in schools that experienced no teacher turnover; in the second quartile an average of 13

\footnotetext{
${ }^{6}$ We examined grade-by-school level growth by creating measure for the difference between years in the number of teachers per grade level per school: Difference $=$ Number of teachers $(n)-$ Number of teachers ( $n-1)$. By averaging difference scores across years and school-by-grade levels we calculated a mean difference score of about 0.3 for our sample. This suggests an average yearly growth of 0.3 teachers within a grade level within a school.
} 
percent of teachers left, in the third quartile approximately one-quarter left, and in the fourth quartile over one-half left. As compared to school-by-grades in the top quartile of turnover, those in the bottom quartile had more high-achieving and Asian students, fewer poor, black, and Hispanic students, and fewer student absences and suspensions.

Table 6 shows the estimates for the effects of teacher turnover on student achievement by quartile of turnover. The first column displays estimates for models employing school-by-year fixed effects, while estimates in the second column come from models with school-by-grade fixed effects. All models control for student, classroom, and school characteristics. Depending on the model and signal for turnover, students experiencing rates of teacher turnover in the second quartile have statistically similar to 1 percent of a standard deviation higher math achievement as compared to students experiencing the least (bottom quartile) teacher turnover. Students in the third quartile are scoring 1.5 to 2 percent of a standard deviation lower, while those in the fourth quartile are scoring about 3 percent of a standard deviation lower. This suggests that reducing teacher attrition rates from one-quarter of teachers leaving to none corresponds with an increase in student math achievement of about 2 percent of a standard deviation. Reducing teacher attrition rates from approximately one-half to none corresponds with an increase of about 3 percent of a standard deviation, an amount that other researchers have suggested to be meaningful. Given there are about 6 teachers per every grade-by-school, in an average grade level in an average school this would be the difference between a year (or grade) where three teachers left and one where none left. We are likely underestimating the true effect since we are really identifying idiosyncratic turnover - across grades (within a school and year) or across years (within a grade and school). If being in a systematically high turnover grade level and school has additional negative effects we are missing these additional effects with our identification strategy. 


\section{Are the effects different for different kinds of schools?}

Prior literature suggests that the turnover rates are especially high in schools with more lowperforming and minority students (Scafidi, Stinebrickner, and Sjoquist, 2003; Hanushek, Kain and Rivkin, 2004; Boyd et al., 2010; Boyd, Lankford, Loeb and Wyckoff, 2005). Moreover, it is typically more challenging to fill vacancies in these kinds of schools with qualified teachers (Boyd et al., 2011). Thus, many have argued that the effects of teacher turnover are probably most harmful to students in schools with underserved student populations. However, estimates in the recent study by Hanushek and Rivkin (2010) suggest the opposite to be true -- that turnover may exert a lower cost on schools with higher populations of low-achieving and black students as compared to schools with fewer of these student populations.

In order to examine this matter further, we analyzed whether the effects of teacher turnover were similar or different in schools with more low-achieving and black students as compared to schools with fewer of these student populations. We did this by re-running analyses separately only with schools whose students averaged below the test score mean and then only with schools that had at least 20 percent black students. ${ }^{7}$ For comparison's sake, we also examined schools with students scoring at or above the mean on test scores, and with black student populations of less than or equal to 20 percent.

Table 7a presents results for models using school-by-grade fixed effects, while Table $7 \mathrm{~b}$ presents results for models using school-by-year fixed effects. Across math and ELA, and across measures for teacher turnover, the negative effect of teacher turnover on student achievement was larger in schools with higher proportions of low-achieving and black students. The results were

\footnotetext{
${ }^{7}$ We used 20 percent as the cutoff score as this was close to the median value. This assured we had similar number of observations in each group: 314,000 in schools with 20 percent or more and 309,000 in schools with less than 20 percent of students that were black.
} 
particularly striking in relation to ELA test scores. Regardless of the model specification, the harmful effects of turnover on ELA achievement were generally two to four times stronger in schools with larger proportions of black and low-achieving students, as compared to schools with smaller proportions of these typically underserved populations. ELA estimates did not even reach statistically significant levels in schools with few low-achieving and black students.

In math, estimates were negative and significant in both low and high achieving schools, but were larger in low-achieving schools. In models using school-by-grade fixed effects, estimates were about twice as big. However, in models using school-by-year fixed effects, the estimates were only marginally bigger in math. Similarly, estimates for the effect of turnover on math achievement were consistently negative and significant in schools with large and small proportions of black students. Again, effects sizes were consistently larger in schools with large proportions of black students.

Tables 8a and 8b compare estimates for old (more than 10 years old) versus new (10 or fewer years old) schools and for big (8 or more teachers per grade level) versus small schools (fewer than 8 teachers per grade level). Across models, estimates are negative and mostly significant, suggesting that turnover has a harmful effect of on student achievement across kinds of schools. While the estimated turnover effects are negative and generally significant in new and small schools, they are larger in magnitude in old and big schools. These results indicate that new school reforms in NYC are not driving the negative effects of turnover described above.

\section{What explains the relationship between teacher turnover and student achievement?}

There are many possible mechanisms by which teacher turnover can harm student achievement. As described in the introduction, prior literature often focuses on the relationships between teacher turnover and teacher quality to explain this effect. The assumed theory of action is that teacher turnover changes the average effectiveness of teachers in the schools that, in turn, 
changes student outcomes. More specifically, the effect of turnover is driven by the relative effectiveness of the teachers who leave a school, as compared to those who replace them. We test this by including in our models two signals for teacher quality - experience and lagged value-added to test whether changes in teaching experience or prior effectiveness at raising test scores explain the harmful effects of turnover on student achievement that we observe. To measure experience we used indicators variables for each year of experience up to 20 years. Because the first year in a school may be especially difficult, even for experienced teachers, we also added a control for whether the teacher moved from a different school.

Tables $9 \mathrm{a}$ and $9 \mathrm{~b}$ show estimates for models examining whether teaching experience and migration explain the effects of teacher turnover on student achievement. We begin with the base model in Model 1, add experience indicators in Model 2, and then add an indicator for whether a teacher is new to the school (mover or first year teacher) in Model 3. Table 7a describes results for models using school-by-grade fixed effects; Table $7 \mathrm{~b}$ describes models using school-by-year fixed effects. In both tables, Model 2 estimates are consistently lower than those in Model 1 but still statistically significant. These results indicate that changes in teacher experience explain some of the effect teacher turnover on student achievement, although a significant amount of the effect remains unexplained. Compared to Model 2, Model 3 estimates are also somewhat smaller but still statistically significant. These results suggest that teachers who migrated from other schools were, on average, less effective, and that this accounted for some of the harmful effects of teacher turnover on student achievement. However, Model 3 estimates remained statistically significant indicating other factors, beyond teaching experience and migration, also explain the effects of teacher turnover on student achievement.

One of the most likely remaining explanatory factors is teachers' prior effectiveness at improving student achievement (Hanushek and Rivkin, 2010). While there is no perfect way of 
measuring teacher effectiveness, regression-based, value-added measures are the current standard. We can calculate value-added measures for a subsample of teachers in the sample. ${ }^{8}$ As a result of missing data, our overall sample sizes were reduced by almost half - for math, student observations reduced from about 625,000 to about 382,000 ; for ELA, observations reduced from 515,707 to 302,072. Tables 10a and 10b show estimates for models using only the subsample of teachers for whom we have data on prior value-added. Model 1 include estimates for the effect of teacher turnover on student achievement for this subsample; Model 2 controls for teachers' average prior value-added ${ }^{9}$ to see if prior effectiveness explains any observed effects in Model 1. These tables show that, even with the reduced sample of teachers for whom we have data on prior value-added, the estimates of the effects of teacher turnover on student achievement remain negative and mostly significant, though were somewhat smaller. After controlling for teachers' average prior value-added, estimate sizes reduce substantially and are generally no longer statistically significant. These results suggest that changes in teachers' effectiveness explain much of the observed relationship between teacher turnover and student achievement, although the substantially diminished power as a result of the reduced sample may have driven these results.

Because we found the effects of teacher turnover to be especially deleterious in lowerachieving schools, we reproduce the value-added analyses separately in lower-achieving and higherachieving schools. Tables $10 \mathrm{a}$ and $10 \mathrm{~b}$ shows that, with the reduced sample, the turnover effect is negative and significant in lower-achieving schools, but that there is no significant effect in higherachieving schools. Moreover, the effect of teacher turnover remains negative and, in most cases, statistically significant even after controlling for prior value-added. Thus, teachers' prior

\footnotetext{
${ }^{8}$ All first year teachers are dropped from this analysis because we do not have student test score data in prior years. For experienced teachers we were unable to estimate value-added for all prior years. To keep our sample as large as possible we decided to use the average of all prior value added estimates as a signal for prior effectiveness.

9 A teacher's average prior value added is the mean of all of his/her prior value added scores.
} 
effectiveness does not appear to explain fully the harmful effects of turnover on student achievement in lower-achieving schools.

If not teacher experience, migration, or prior effectiveness, then what else might account for the harmful effects of teacher turnover on student achievement, particularly in low-achieving schools? It is beyond the scope of this study to identify and test all possible mechanisms by which turnover may harm student achievement. However, one way to begin to identify how turnover impacts student achievement is to examine whether the effects of teacher turnover accrue only to students who have teachers who are new to the grade-level team in their school or whether the effects of turnover are also felt by students whose teachers had remained. If the students of stayers are harmed by teacher turnover, it would cast further doubt on the hypothesis that turnover harms student achievement only through the relative effectiveness of the teachers who leave as compared to those that replace them. It would suggest that the rotation of teachers has an influence beyond just those students of teachers who were coming and going, to somehow negatively impact even the students who were assigned to teachers who stayed in the same school from year to year. To test this, we examined the effects of turnover separately for teachers who were stayers, movers, and rookies (first year) to see the extent to which the students of these groups of teachers experienced the effects of turnover differently. Given prior evidence that the effect of turnover manifests primarily in lower-achieving schools, we continued to analyze low and high achieving schools separately.

Table 11a shows the results for models using school-by-grade fixed effects while Table 11b shows results for models using school-by-year fixed effects. There is a consistent pattern for stayers - in lower achieving schools, their students perform significantly worse when turnover is greater; while in higher-achieving schools there is no effect. For movers, the effects of turnover vary according to model specifications, and there is no clear pattern as to whether turnover is more or 
less harmful in lower or higher achieving settings. In general, there is a negative relationship between turnover and achievement for students of movers, although the effect is not always significant. Lastly, there are no significant effects of turnover on the student achievement of first year teachers, regardless of model or kind of school. This result suggests that first year teachers do equally well at improving student achievement regardless of the turnover rate in their grade.

\section{DISCUSSION}

This study finds some of the first empirical evidence for a direct effect of teacher turnover on student achievement. Results demonstrate that teacher turnover has a significant and negative effect on student achievement in both math and ELA. Moreover, teacher turnover is particularly harmful to students in schools with large populations of low-performing and black students.

Much of the existing literature assumes that teacher turnover impacts student achievement by changing the average quality of teachers in schools. That is, if the teachers who leave a school are worse than those who replace them, then turnover will have a net positive effect. In this view, stayers are merely bystanders who do not affect and are not affected by turnover.

Although this study finds evidence that changes in teacher quality explain some of the effect of turnover on student achievement, the results suggest there may be disruptional effects of turnover beyond these compositional effects. First, results show that turnover has a harmful effect on student achievement, even after controlling for different indicators of teacher quality, especially in lower-performing schools. Also, we find that turnover negatively affects the students of stayers those who remain in the same school from one year to the next as well the students in the classrooms of new teachers. Thus, turnover must have an impact beyond simply whether incoming teachers are better than those they replaced - even the teachers outside of this redistribution were somehow harmed by it. Although this study does not identify the specific mechanism by which 
turnover harms students, it provides guidance on where to look. The findings indicate that turnover has a broader, harmful influence on student achievement since it can reach beyond just those students of teachers who left or of those that replaced them. Any explanation for the effect of turnover must possess these characteristics. One possibility is that turnover negatively affects collegiality or relational trust among faculty; or perhaps turnover results in loss of institutional knowledge among faculty that is critical for supporting all student learning. More research is needed to identify the specific mechanism.

This study also makes methodological contributions. Often the effects of turnover are analyzed at the school-level, an approach that makes the questionable assumption that the effects of turnover are comparable across different kinds of schools. Instead, we utilize two innovative modeling approaches that do not make this assumption. The first identifies turnover variation across years within the same grade level and within the same school to examine whether students had better or worse test score gains in a given year, as compared to other years when teacher turnover was at different rates. The second identifies turnover variation across grade levels within the same year and within the same school to examine whether students in grade levels with higher or lower turnover rates also had higher or lower achievement gains. Though an improvement over school-level analyses, both of these methods also make questionable assumptions. The former assumes the effects of turnover rates within the same grade and school are comparable across years; the latter assumes that turnover effects within the same school and year are comparable across grade levels. Despite concerns over potential bias introduced by these assumptions, that findings were similar across methodological approaches suggests that we may have detected a true effect.

Finally, the findings of this study also have policy implications. Though there may be cases where turnover is actually helpful to student achievement, on average, it is harmful. One possibility might be to introduce incentive structures to retain teachers that might leave otherwise. 
Implementing such policies may be especially important in schools with large populations of lowperforming and black students, where turnover has the strongest negative effect on student achievement. 


\section{REFERENCES}

Abelson, M. A., \& Baysinger, B. D. (1984). Optimal and dysfunctional turnover: Toward an organizational level model. The Academy of Management Review, Vol. 9, No. 2 (Apr., 1984), pp. 331-341

Boyd, D., Lankford, H., Loeb, S., Ronfeldt, M., \& Wyckoff, J. (2011). The role of teacher quality in retention and hiring: Using applications-to-transfer to uncover preferences of teachers and schools. Journal of Policy and Management, Vol. 30(1), pp. 88-2011.

Boyd, D., Lankford, H., Loeb, S., Ronfeldt, M., \& Wyckoff, J. (2010). The effects of school neighborhoods on teacher career decisions. Working paper downloaded from: http://www.teacherpolicyresearch.org/portals/1/pdfs/School $\% 20$ Neighborhoods $\% 20$ Teacher $\% 20$ Retention.pdf

Boyd, D., Lankford, H., Loeb, S., \& Wyckoff, J. (2005). Explaining the short careers of highachieving teachers in schools with low-performing students. American Economic Review, 95(2) pp. 166171.

Bryk, A.S. \& Schneider, B. (2002). Trust in schools: A core resource for improvement. New York: Russell Sage Foundation.

Goldhaber, D., Gross, B., Player, D. (2007). Are public schools really losing their "best"? Assessing the career transitions of teachers and their implications for the quality of the teacher workforce. Washington, D.C.: National Center for Analysis of Longitudinal Data in Education Research.

Guin, K. (2004). Chronic teacher turnover in urban elementary schools. Educational Evaluation and Policy Analysis, Vol. 12, No. 42, 1-25.

Ingersoll, R. (2001). Teacher turnover and teacher shortages: An organizational analysis. American Educational Research Journal, Vol. 38, No. 3, pp. 499-534.

Hanushek, E.A., Kain, J.F. \& Rivkin, S.G. (1999). Do higher salaries buy better teachers? Working paper No. 7082. Cambridge, MA: National Bureau of Economic Research.

Hanushek, E., Kain, J., \& Rivkin, S. (2004). Why public schools lose teachers. Journal of Human Resources, 39(2), pp. 326-54.

Hanushek, E. \& Rivkin, S. (2010) Constrained job matching: Does teacher job search harm disadvantaged urban schools? Working paper No. 15816. Cambridge, MA: National Bureau of Economic Research.

Scafidi, B., Stinebrickner, T., \& Sjoquist, D. L. (2003). The relationship between school characteristics and teacher mobility. Working paper, Georgia State University. 


\section{FIGURES}

FIGURE A: Distribution of Number of Teachers per School-by-Grade

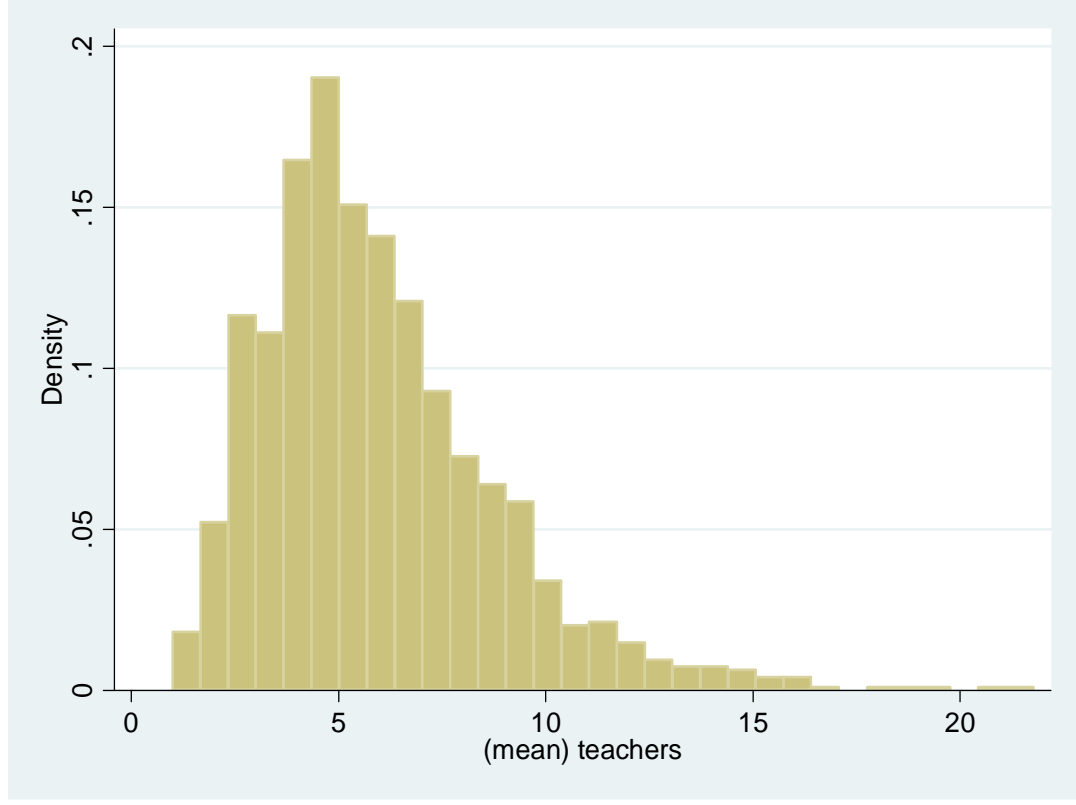

FIGURE B: Distribution of "Lagged Attrition" Turnover Measure

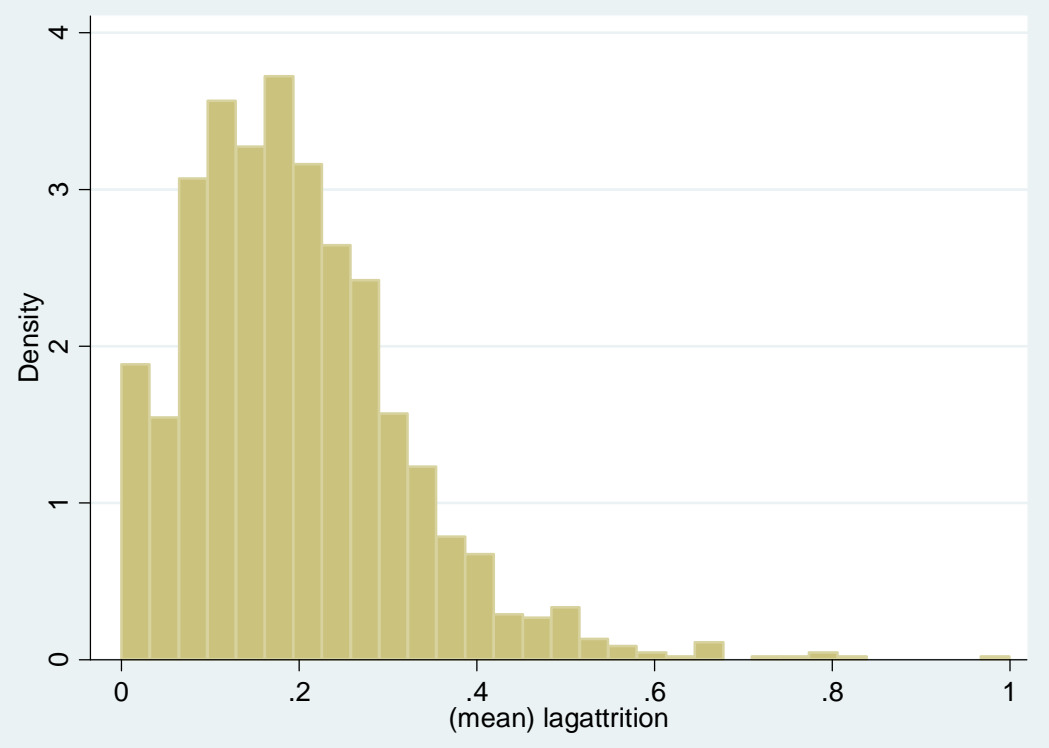


FIGURE C: Distribution of "Proportion New" Turnover Measure

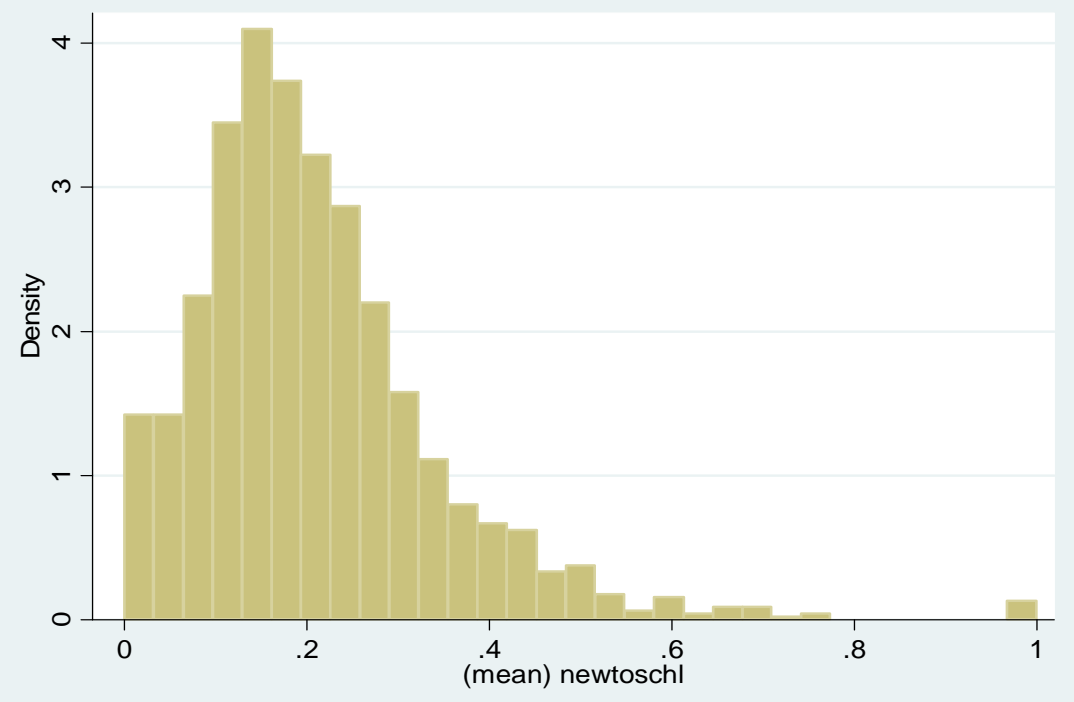




\section{TABLES}

TABLE 1: Student, Teacher, and School-by-Grade Characteristics

\begin{tabular}{|c|c|}
\hline STUDENT CHARACTERISTICS & Mean \\
\hline Proportion Female & 0.51 \\
\hline Proportion Hispanic & 0.36 \\
\hline Proportion Black & 0.33 \\
\hline Proportion Asian & 0.14 \\
\hline Proportion Other Ethnic & 0.00 \\
\hline Proportion Caucasian & 0.27 \\
\hline Proportion Free Lunch & 0.61 \\
\hline Proportion Home Language English & 0.63 \\
\hline Proportion Suspended in Prior Year & 0.02 \\
\hline Proportion Changing Schools from Prior Year & 0.09 \\
\hline Average Number of Absences in Prior Year & $10.75(10.20)$ \\
\hline Grade 4 Observations (Student-Year) & 253,071 \\
\hline Grade 5 Observations (Student-Year) & 262,636 \\
\hline Observations (Student-Year) & 515,707 \\
\hline TEACHER-YEAR CHARACTERISTICS & Mean \\
\hline Experience & $6.03(5.84)$ \\
\hline Proportion Stayers & 0.82 \\
\hline Proportion Movers & 0.04 \\
\hline Proportion First Years & 0.12 \\
\hline Proportion Unknown Status & 0.02 \\
\hline Observations (Teacher-Year) & 24917 \\
\hline GRADE-BY-SCHL CHARACTERISTICS & Mean \\
\hline Teachers & $5.95(2.83)$ \\
\hline Turnover Rate (Lagged Attrition) & $0.20(0.12)$ \\
\hline Zero Lagged Attrition & $0.37(0.27)$ \\
\hline Total Lagged Attrition & $0.02(0.07)$ \\
\hline Turnover Rate (Proportion New to School) & $0.21(0.13)$ \\
\hline Zero New to School & $0.36(0.26)$ \\
\hline Total New to School & $0.03(0.09)$ \\
\hline Observations (School-Grade) & 1395 \\
\hline
\end{tabular}


Table 2: Estimates of the Effects of Teacher Turnover on Student Achievement, Using School-By-Grade Fixed Effects

\begin{tabular}{llcc}
\hline Test & Turnover Measure & Model 1 & Model 2 \\
\hline Math & Proportion New To School & $-0.0709^{* * *}$ & $-0.0640^{* * *}$ \\
& Lagged Attrition & $(0.010)$ & $(0.010)$ \\
& & $-0.0613^{* * *}$ & $-0.0590^{* * *}$ \\
& & $(0.010)$ & $(0.010)$ \\
ELA & Proportion New To School & $-0.0613^{* * *}$ & $-0.0511^{* * *}$ \\
& Lagged Attrition & $(0.010)$ & $(0.010)$ \\
& & $-0.0294^{* *}$ & $-0.0296^{* *}$ \\
& School-By-Grade Fixed Effects & $(0.010)$ & $(0.010)$ \\
& Year Indicators & $\mathrm{x}$ & $\mathrm{x}$ \\
& Student, Class, School Controls & $\mathrm{x}$ & $\mathrm{x}$ \\
\hline
\end{tabular}

TABLE 3: Examining Measures of Turnover in Growth, Decline, and Constant Years

\begin{tabular}{|c|c|c|c|}
\hline $\begin{array}{l}\text { Hypothetical: } \\
\text { Grade } 4 \text { in School A }\end{array}$ & Example & $\begin{array}{l}\text { Turnover Rate Using Lagged } \\
\text { Attrition } \\
\text { (\# who left in 04-05) / } \\
\text { (total \# in 04-05) }\end{array}$ & $\begin{array}{l}\text { Turnover Rate Using } \\
\text { Proportion New } \\
\text { (\# new in 05-06) / } \\
\text { (total \# in 05-06) }\end{array}$ \\
\hline Growth: Increase in Number & 2004-05: 6 teachers & Turnover Rate $=0 / 6$ & Turnover Rate $=1 / 7$ \\
\hline of Teachers & $\begin{array}{l}\text { 2005-2006: } 7 \text { teachers } \\
\text { (6 stayers, } 1 \text { mover) }\end{array}$ & Turnover Rate $=0$ & Turnover Rate $=0.14$ \\
\hline Decline: Decrease in & 2004-05: 7 teachers & Turnover Rate $=1 / 7$ & Turnover Rate $=0 / 6$ \\
\hline Number of Teachers & $\begin{array}{l}\text { 2005-2006: } 6 \text { teachers } \\
\text { (6 stayers) }\end{array}$ & Turnover Rate $=0.14$ & Turnover Rate $=0$ \\
\hline Constant: Number of & 2004-05: 6 teachers & Turnover Rate $=1 / 6$ & Turnover Rate $=1 / 6$ \\
\hline Teachers is Constant & $\begin{array}{l}\text { 2005-2006: } 6 \text { teachers } \\
\text { (5 stayers, } 1 \text { mover) }\end{array}$ & Turnover Rate $=0.17$ & Turnover Rate $=0.17$ \\
\hline
\end{tabular}


Table 4: Estimates of Effects of Teacher Turnover on Student Achievement, Using SchoolBy-Year Fixed Effects

\begin{tabular}{llcc}
\hline Test & Turnover Measure & Model 1 & Model 2 \\
\hline Math & Proportion New To School & $-0.0704^{* * *}$ & $-0.0682^{* * *}$ \\
& & $(0.012)$ & $(0.012)$ \\
& Lagged Attrition & $-0.0544^{* * *}$ & $-0.0559^{* * *}$ \\
& & $(0.012)$ & $(0.012)$ \\
ELA & Proportion New To School & $-0.0723^{* * *}$ & $-0.0713^{* * *}$ \\
& & $(0.013)$ & $(0.013)$ \\
& Lagged Attrition & $-0.0359^{* *}$ & $-0.0387^{* *}$ \\
& & $(0.013)$ & $(0.013)$ \\
& & & \\
& School-By-Year Fixed Effects & $\mathrm{x}$ & $\mathrm{x}$ \\
& Grade Indicators & $\mathrm{x}$ & $\mathrm{x}$ \\
& Student, Class, School Controls & & $\mathrm{x}$ \\
\hline
\end{tabular}

Table 5: School-Grade-Year Level Descriptive Statistics by Quartile of Lagged Attrition

\begin{tabular}{lcccc}
\hline Variable & Quartile 1 & Quartile 2 & Quartile 3 & Quartile 4 \\
\hline Lagged Attrition & 0.00 & 0.13 & 0.26 & 0.55 \\
Math Test Score (standardized) & 0.20 & 0.11 & 0.05 & -0.07 \\
Proportion Free/Reduced Lunch & 0.58 & 0.65 & 0.66 & 0.70 \\
Proportion Hispanic & 0.32 & 0.40 & 0.37 & 0.39 \\
Proportion Black & 0.32 & 0.31 & 0.38 & 0.42 \\
Proportion Asian & 0.15 & 0.14 & 0.11 & 0.08 \\
Proportion "Other" Race/Ethnicity & 0.00 & 0.00 & 0.00 & 0.01 \\
Proportion Female & 0.51 & 0.51 & 0.52 & 0.52 \\
Lagged Number of Absences & 10.59 & 10.84 & 11.26 & 12.03 \\
Lagged Proportion Suspended & 0.02 & 0.02 & 0.02 & 0.03 \\
\hline
\end{tabular}


Table 6: Estimates of Effects of Teacher Turnover on Student Achievement by Quartile of Teacher Turnover (Bottom Quartile is Reference Group)

\begin{tabular}{lcc}
\hline Turnover Measure & Model 1 & Model 2 \\
\hline Lagged Attrition Q2 & 0.0036 & $-0.0128^{*}$ \\
Lagged Attrition Q3 & $(0.007)$ & $(0.006)$ \\
Lagged Attrition Q4 & $-0.0167^{* *}$ & $-0.0199^{* * *}$ \\
& $(0.006)$ & $(0.005)$ \\
& $-0.0294^{* * *}$ & $-0.0296^{* * *}$ \\
Turnover Measure & $(0.007)$ & $(0.006)$ \\
New to Grade-by-School Q2 & -0.0088 & -0.0055 \\
& $(0.007)$ & $(0.006)$ \\
New to Grade-by-School Q3 & $-0.0192^{* *}$ & $-0.0145^{* *}$ \\
& $(0.006)$ & $(0.005)$ \\
New to Grade-by-School Q4 & $-0.0309^{* * *}$ & $-0.0336^{* * *}$ \\
& $(0.007)$ & $(0.006)$ \\
Student, Class, School Controls & $\mathrm{x}$ & $\mathrm{x}$ \\
School-by-Year Fixed Effects & $\mathrm{x}$ & $\mathrm{x}$ \\
Grade Indicators & $\mathrm{x}$ & $\mathrm{x}$ \\
School-by-Grade Fixed Effects & & \\
Year Indicators & & \\
\hline
\end{tabular}


Table 7a: Estimates of Effects of Teacher Turnover on Student Achievement at Different Kinds of Schools (achievement and race), Using School-By-Grade Fixed Effects

\begin{tabular}{|c|c|c|c|c|c|}
\hline Test & Turnover Measure & High Ach. & Low Ach. & High Black & Low Black \\
\hline \multirow[t]{4}{*}{ Math } & Proportion New To School & $-0.0359 *$ & $-0.0775^{* * *}$ & $-0.0678^{* * *}$ & $-0.0488^{* *}$ \\
\hline & & $(0.016)$ & $(0.013)$ & $(0.013)$ & $(0.016)$ \\
\hline & Lagged Attrition & $-0.0521 * * *$ & $-0.0762 * * *$ & $-0.0830 * * *$ & $-0.0446 * *$ \\
\hline & & $(0.015)$ & $(0.013)$ & $(0.013)$ & $(0.015)$ \\
\hline \multirow[t]{7}{*}{ ELA } & Proportion New To School & -0.0184 & $-0.0432 * * *$ & $-0.0348^{* *}$ & -0.0196 \\
\hline & & $(0.017)$ & $(0.013)$ & $(0.013)$ & $(0.016)$ \\
\hline & Lagged Attrition & $-0.0265 \sim$ & $-0.0778^{* * *}$ & $-0.0830 * * *$ & $-0.0446 * *$ \\
\hline & & $(0.0157)$ & $(0.0122)$ & $(0.013)$ & $(0.015)$ \\
\hline & School-By-Grade Fixed Effects & $\mathrm{x}$ & $\mathrm{x}$ & $\mathrm{x}$ & $\mathrm{x}$ \\
\hline & Year Indicators & $\mathrm{x}$ & $\mathrm{x}$ & $\mathrm{x}$ & $\mathrm{x}$ \\
\hline & Student, Class, School Controls & $\mathrm{x}$ & $\mathrm{x}$ & $\mathrm{x}$ & $\mathrm{x}$ \\
\hline
\end{tabular}

Table 7b: Estimates of Effects of Teacher Turnover on Student Achievement at Different Kinds of Schools (achievement and race), Using School-By-Year Fixed Effects

\begin{tabular}{|c|c|c|c|c|c|}
\hline Test & Turnover Measure & High Ach. & Low Ach. & High Black & Low Black \\
\hline \multirow[t]{4}{*}{ Math } & Proportion New To School & $-0.0514 * *$ & $-0.0600 * * *$ & $-0.0589 * * *$ & $-0.0517^{* *}$ \\
\hline & & $(0.019)$ & $(0.015)$ & $(0.016)$ & $(0.018)$ \\
\hline & Lagged Attrition & $-0.0443^{*}$ & $-0.0999 * * *$ & $-0.0930 * * *$ & $-0.0431^{*}$ \\
\hline & & $(0.018)$ & $(0.015)$ & $(0.015)$ & $(0.018)$ \\
\hline \multirow[t]{7}{*}{ ELA } & Proportion New To School & -0.0032 & $-0.0735^{* * *}$ & $-0.0557 * *$ & -0.0188 \\
\hline & & $(0.020)$ & $(0.016)$ & $(0.017)$ & $(0.019)$ \\
\hline & Lagged Attrition & -0.0317 & $-0.1164 * * *$ & $-0.1006^{* * *}$ & $-0.0366 \sim$ \\
\hline & & $(0.020)$ & $(0.016)$ & $(0.018)$ & $(0.019)$ \\
\hline & School-By-Year Fixed Effects & $\mathrm{x}$ & $\mathrm{x}$ & $\mathrm{x}$ & $\mathrm{x}$ \\
\hline & Grade Indicators & $\mathrm{x}$ & $\mathrm{x}$ & $\mathrm{x}$ & $\mathrm{x}$ \\
\hline & Student, Class, School Controls & $\mathrm{x}$ & $\mathrm{x}$ & $\mathrm{x}$ & $\mathrm{x}$ \\
\hline
\end{tabular}


Table 8a: Estimates of Effects of Teacher Turnover on Student Achievement at Different Kinds of Schools (age and size), Using School-By-Grade Fixed Effects

\begin{tabular}{|c|c|c|c|c|c|}
\hline Test & Turnover Measure & New & Old & Small & Big \\
\hline \multirow[t]{4}{*}{ Math } & Proportion New To School & $-0.0238 \sim$ & $-0.0661 * * *$ & $-0.0570 * * *$ & $-0.0679 * *$ \\
\hline & & $(0.014)$ & $(0.014)$ & $(0.011)$ & $(0.026)$ \\
\hline & Lagged Attrition & $-0.0296^{*}$ & $-0.0816^{* * *}$ & $-0.0616^{* * *}$ & $-0.0701 * *$ \\
\hline & & $(0.012)$ & $(0.013)$ & $(0.011)$ & $(0.026)$ \\
\hline \multirow[t]{7}{*}{ ELA } & Proportion New To School & -0.0084 & $-0.0449 * * *$ & $-0.0209 \sim$ & -0.0347 \\
\hline & & $(0.025)$ & $(0.012)$ & $(0.012)$ & $(0.024)$ \\
\hline & Lagged Attrition & $-0.0479 *$ & $-0.0565^{* * *}$ & $-0.0603^{* * *}$ & -0.0114 \\
\hline & & $(0.022)$ & $(0.013)$ & $(0.011)$ & $(0.026)$ \\
\hline & School-By-Grade Fixed Effects & $\mathrm{x}$ & $\mathrm{x}$ & $\mathrm{x}$ & $\mathrm{x}$ \\
\hline & Year Indicators & $\mathrm{x}$ & $\mathrm{x}$ & $\mathrm{x}$ & $\mathrm{x}$ \\
\hline & Student, Class, School Controls & $\mathrm{x}$ & $\mathrm{x}$ & $\mathrm{x}$ & $\mathrm{x}$ \\
\hline
\end{tabular}

Table 8b: Estimates of Effects of Teacher Turnover on Student Achievement at Different Kinds of Schools (age and size), Using School-By-Year Fixed Effects

\begin{tabular}{|c|c|c|c|c|c|}
\hline Test & Turnover Measure & New & Old & Small & Big \\
\hline \multirow[t]{4}{*}{ Math } & Proportion New To School & $-0.0368^{*}$ & $-0.0659 * * *$ & $-0.0547 * * *$ & -0.0539 \\
\hline & & $(0.017)$ & $(0.019)$ & $(0.014)$ & $(0.038)$ \\
\hline & Lagged Attrition & $-0.0407 *$ & $-0.0992^{* * *}$ & $-0.0425^{* *}$ & $-0.1377 * * *$ \\
\hline & & $(0.016)$ & $(0.019)$ & $(0.014)$ & $(0.037)$ \\
\hline \multirow[t]{7}{*}{ ELA } & Proportion New To School & $-0.0386 \sim$ & $-0.0404 * *$ & -0.0241 & $-0.0951 *$ \\
\hline & & $(0.023)$ & $(0.015)$ & $(0.015)$ & $(0.038)$ \\
\hline & Lagged Attrition & $-0.0568^{*}$ & $-0.0743^{* * *}$ & $-0.0503^{* *}$ & $-0.0896^{*}$ \\
\hline & & $(0.023)$ & $(0.015)$ & $(0.015)$ & $(0.040)$ \\
\hline & School-By-Year Fixed Effects & $\mathrm{x}$ & $\mathrm{x}$ & $\mathrm{x}$ & $\mathrm{x}$ \\
\hline & Grade Indicators & $\mathrm{x}$ & $\mathrm{x}$ & $\mathrm{x}$ & $\mathrm{x}$ \\
\hline & Student, Class, School Controls & $\mathrm{x}$ & $\mathrm{x}$ & $\mathrm{x}$ & $\mathrm{x}$ \\
\hline
\end{tabular}


Table 9a : Examining Whether Teacher Experience and Migration Explains Effects of Turnover on Student Achievement, Using School-by-Grade Fixed Effects

\begin{tabular}{|c|c|c|c|c|}
\hline Test & Turnover Measure & Model 1 & Model 2 & Model 3 \\
\hline \multirow[t]{4}{*}{ Math } & Proportion New To School & $-0.0640 * * *$ & $-0.0324 * * *$ & $-0.0240^{*}$ \\
\hline & & $(0.010)$ & $(0.010)$ & $(0.010)$ \\
\hline & Lagged Attrition & $-0.0590 * * *$ & $-0.0419 * * *$ & $-0.0358^{* * *}$ \\
\hline & & $(0.010)$ & $(0.010)$ & $(0.010)$ \\
\hline \multirow[t]{9}{*}{ ELA } & Proportion New To School & $-0.0511 * * *$ & $-0.0247 *$ & $-0.0213^{*}$ \\
\hline & & $(0.010)$ & $(0.010)$ & $(0.010)$ \\
\hline & Lagged Attrition & $-0.0296 * *$ & -0.0158 & -0.0126 \\
\hline & & $(0.010)$ & $(0.010)$ & $(0.010)$ \\
\hline & School-By-Grade Fixed Effects & $\mathrm{x}$ & $\mathrm{x}$ & $\mathrm{x}$ \\
\hline & Year Indicators & $\mathrm{x}$ & $\mathrm{x}$ & $\mathrm{x}$ \\
\hline & Student, Class, School Controls & $\mathrm{x}$ & $\mathrm{x}$ & $\mathrm{x}$ \\
\hline & Experience Indicators & & $\mathrm{x}$ & $\mathrm{x}$ \\
\hline & Mover Indicator & & & $\mathrm{x}$ \\
\hline
\end{tabular}

Table 9b : Examining Whether Teacher Experience and Migration Explains Effects of Turnover on Student Achievement, Using School-by-Year Fixed Effects

\begin{tabular}{llccc}
\hline Test & Turnover Measure & Model 1 & Model 2 & Model 3 \\
\hline Math & Proportion New To School & $-0.0682^{* * *}$ & $-0.0333^{* *}$ & $-0.0246^{*}$ \\
& & $(0.012)$ & $(0.012)$ & $(0.012)$ \\
& Lagged Attrition & $-0.0559^{* * *}$ & $-0.0439^{* * *}$ & $-0.0405^{* * *}$ \\
& & $(0.012)$ & $(0.012)$ & $(0.012)$ \\
& & & & \\
ELA & Proportion New To School & $-0.0713^{* * *}$ & $-0.0380^{* *}$ & $-0.0322^{*}$ \\
& & $(0.013)$ & $(0.013)$ & $(0.013)$ \\
& Lagged Attrition & $-0.0387^{* *}$ & $-0.0265^{*}$ & -0.0204 \\
& & $(0.013)$ & $(0.013)$ & $(0.013)$ \\
& & & & \\
& School-By-Year Fixed Effects & $\mathrm{x}$ & $\mathrm{x}$ & $\mathrm{x}$ \\
& Grade Indicators & $\mathrm{x}$ & $\mathrm{x}$ & $\mathrm{x}$ \\
& Student, Class, School Controls & $\mathrm{x}$ & $\mathrm{x}$ & $\mathrm{x}$ \\
Experience Indicators & & $\mathrm{x}$ & $\mathrm{x}$ \\
Mover Indicator & & $\mathrm{x}$ \\
\hline
\end{tabular}


TABLE 10a: Estimating Whether Prior Value-Added Explains Effects of Teacher Turnover, School-by-Grade Fixed Effects

\begin{tabular}{|c|c|c|c|c|c|c|}
\hline Math & \multicolumn{2}{|c|}{ All Schools } & \multicolumn{2}{|c|}{ Low Performing } & \multicolumn{2}{|c|}{ High Performing } \\
\hline Lagged Attrition & $\begin{array}{c}-0.0320^{*} \\
(0.0131)\end{array}$ & $\begin{array}{c}-0.0209 \sim \\
(0.0125)\end{array}$ & $\begin{array}{c}-0.0509^{* *} \\
(0.0169)\end{array}$ & $\begin{array}{c}-0.0388^{*} \\
(0.0170)\end{array}$ & $\begin{array}{l}-0.0126 \\
(0.0202)\end{array}$ & $\begin{array}{c}0.0028 \\
(0.0187)\end{array}$ \\
\hline Proportion New & $\begin{array}{c}-0.0348^{* *} \\
(0.0126)\end{array}$ & $\begin{array}{c}-0.0226 \sim \\
(0.0124)\end{array}$ & $\begin{array}{c}-0.0557 * * * \\
(0.0166)\end{array}$ & $\begin{array}{c}-0.0445^{* *} \\
(0.0165)\end{array}$ & $\begin{array}{l}-0.0165 \\
(0.0191)\end{array}$ & $\begin{array}{l}-0.0048 \\
(0.0183)\end{array}$ \\
\hline ELA & \multicolumn{2}{|c|}{ All Schools } & \multicolumn{2}{|c|}{ Low Performing } & \multicolumn{2}{|c|}{ High Performing } \\
\hline Lagged Attrition & $\begin{array}{c}-0.0255 \sim \\
(0.0133)\end{array}$ & $\begin{array}{c}-0.0257 \sim \\
(0.0134)\end{array}$ & $\begin{array}{l}-0.0414 * \\
(0.0168)\end{array}$ & $\begin{array}{c}-0.0426^{*} \\
(0.0169)\end{array}$ & $\begin{array}{l}-0.0065 \\
(0.0207)\end{array}$ & $\begin{array}{l}-0.0042 \\
(0.0209)\end{array}$ \\
\hline Proportion New & $\begin{array}{c}-0.0301^{*} \\
(0.0132)\end{array}$ & $\begin{array}{c}-0.0280 * \\
(0.0132)\end{array}$ & $\begin{array}{c}-0.0649 * * * \\
(0.0163)\end{array}$ & $\begin{array}{c}-0.0656^{* * *} \\
(0.0162)\end{array}$ & $\begin{array}{l}-0.0015 \\
(0.0205)\end{array}$ & $\begin{array}{c}0.0037 \\
(0.0206)\end{array}$ \\
\hline School-by-Grade Fixed Effects & $\mathrm{x}$ & $\mathrm{x}$ & $\mathrm{x}$ & $\mathrm{x}$ & $\mathrm{x}$ & $\mathrm{x}$ \\
\hline Year Indicators & $\mathrm{x}$ & $\mathrm{x}$ & $\mathrm{x}$ & $\mathrm{x}$ & $\mathrm{x}$ & $\mathrm{x}$ \\
\hline Student, Class, School Controls & $\mathrm{x}$ & $\mathrm{x}$ & $\mathrm{x}$ & $\mathrm{x}$ & $\mathrm{x}$ & $\mathrm{x}$ \\
\hline Average Prior Value-Added & & $\mathrm{x}$ & & $\mathrm{x}$ & & $\mathrm{x}$ \\
\hline
\end{tabular}

TABLE 10b: Estimating Whether Prior Value-Added Explains Effects of Teacher Turnover, School-by-Year Fixed Effects

\begin{tabular}{|c|c|c|c|c|c|c|}
\hline \multirow{2}{*}{$\begin{array}{l}\text { Math } \\
\text { Lagged Attrition }\end{array}$} & \multicolumn{2}{|c|}{ All Schools } & \multicolumn{2}{|c|}{ Low Performing } & \multicolumn{2}{|c|}{ High Performing } \\
\hline & $\begin{array}{c}-0.0406^{* *} \\
(0.0152)\end{array}$ & $\begin{array}{l}-0.0196 \\
(0.0130)\end{array}$ & $\begin{array}{c}-0.0417 * \\
(0.0197)\end{array}$ & $\begin{array}{l}-0.0286 \\
(0.0180)\end{array}$ & $\begin{array}{c}-0.0392 \sim \\
(0.0232)\end{array}$ & $\begin{array}{l}-0.0094 \\
(0.0190)\end{array}$ \\
\hline Proportion New & $\begin{array}{l}-0.0224 \\
(0.0155)\end{array}$ & $\begin{array}{l}-0.0120 \\
(0.0134)\end{array}$ & $\begin{array}{c}-0.0571 * * \\
(0.0204)\end{array}$ & $\begin{array}{c}-0.0347 \sim \\
(0.0188)\end{array}$ & $\begin{array}{c}0.0016 \\
(0.0229)\end{array}$ & $\begin{array}{c}0.0020 \\
(0.0189)\end{array}$ \\
\hline ELA & \multicolumn{2}{|c|}{ All Schools } & \multicolumn{2}{|c|}{ Low Performing } & \multicolumn{2}{|c|}{ High Performing } \\
\hline Lagged Attrition & $\begin{array}{l}-0.0150 \\
(0.0161)\end{array}$ & $\begin{array}{l}-0.0090 \\
(0.0149)\end{array}$ & $\begin{array}{l}-0.0431 * \\
(0.0207)\end{array}$ & $\begin{array}{c}-0.0502^{*} \\
(0.0196)\end{array}$ & $\begin{array}{c}0.0109 \\
(0.0243)\end{array}$ & $\begin{array}{c}0.0329 \\
(0.0221)\end{array}$ \\
\hline Proportion New & $\begin{array}{c}-0.0433 * * \\
(0.0167)\end{array}$ & $\begin{array}{c}-0.0291 \sim \\
(0.0156)\end{array}$ & $\begin{array}{c}-0.0984 * * * \\
(0.0220)\end{array}$ & $\begin{array}{c}-0.0919 * * * \\
(0.0207)\end{array}$ & $\begin{array}{c}0.0001 \\
(0.0241)\end{array}$ & $\begin{array}{c}0.0229 \\
(0.0225)\end{array}$ \\
\hline School-by-Year Fixed Effects & $\mathrm{x}$ & $\mathrm{x}$ & $\mathrm{x}$ & $\mathrm{x}$ & $\mathrm{x}$ & $\mathrm{x}$ \\
\hline Grade Indicators & $\mathrm{x}$ & $\mathrm{x}$ & $\mathrm{x}$ & $\mathrm{x}$ & $\mathrm{x}$ & $\mathrm{x}$ \\
\hline Student, Class, School Controls & $\mathrm{x}$ & $\mathrm{x}$ & $\mathrm{x}$ & $\mathrm{x}$ & $\mathrm{x}$ & $\mathrm{x}$ \\
\hline Average Prior Value-Added & & $\mathrm{x}$ & & $\mathrm{x}$ & & $\mathrm{x}$ \\
\hline
\end{tabular}


TABLE 11a: Examining the Effect of Teacher Turnover on Stayers, Movers, and Leavers in High and Low Achieving Schools (school-by-grade fixed effects)

\begin{tabular}{|c|c|c|c|c|c|}
\hline & & MATH & & ELA & \\
\hline & $\underline{\text { Turnover Measure }}$ & $\underline{\text { Hi Ach }}$ & $\underline{\text { Lo Ach }}$ & $\underline{\mathrm{Hi} A c h}$ & $\underline{\text { Lo Ach }}$ \\
\hline \multirow[t]{4}{*}{ Stayers Only } & Lagged Attrition & -0.0023 & $-0.0593 * * *$ & 0.0030 & $-0.0253 \sim$ \\
\hline & & $(0.018)$ & $(0.015)$ & $(0.019)$ & $(0.014)$ \\
\hline & Proportion New & 0.0088 & $-0.0338^{*}$ & 0.0095 & $-0.0390 * *$ \\
\hline & & $(0.017)$ & $(0.015)$ & $(0.019)$ & $(0.014)$ \\
\hline \multirow[t]{4}{*}{ Movers Only } & Lagged Attrition & $-0.2038^{* *}$ & -0.0473 & -0.0821 & 0.0000 \\
\hline & & $(0.065)$ & $(0.057)$ & $(0.085)$ & $(0.067)$ \\
\hline & Proportion New & -0.0494 & $-0.1519 *$ & $-0.3023^{* *}$ & $-0.1207 *$ \\
\hline & & $(0.076)$ & $(0.065)$ & $(0.095)$ & $(0.056)$ \\
\hline \multirow[t]{7}{*}{ First Years Only } & Lagged Attrition & 0.0059 & 0.0030 & 0.0274 & 0.0383 \\
\hline & & $(0.035)$ & $(0.028)$ & $(0.034)$ & $(0.030)$ \\
\hline & Proportion New & 0.0213 & 0.0228 & 0.0516 & -0.0068 \\
\hline & & $(0.037)$ & $(0.028)$ & $(0.036)$ & $(0.028)$ \\
\hline & School-by-Grade FE & $\mathrm{x}$ & $\mathrm{x}$ & $\mathrm{x}$ & $\mathrm{x}$ \\
\hline & Year Indicators & $\mathrm{x}$ & $\mathrm{x}$ & $\mathrm{x}$ & $\mathrm{x}$ \\
\hline & Student, School, Class Controls & $\mathrm{x}$ & $\mathrm{x}$ & $\mathrm{x}$ & $\mathrm{x}$ \\
\hline
\end{tabular}


TABLE 11b: Examining the Effect of Teacher Turnover on Stayers, Movers, and Leavers in High and Low Achieving Schools (school-by-year fixed effects)

\begin{tabular}{|c|c|c|c|c|c|}
\hline & & MATH & & ELA & \\
\hline & $\underline{\text { Turnover Measure }}$ & $\underline{\text { Hi Ach }}$ & $\underline{\text { Lo Ach }}$ & $\underline{\text { Hi Ach }}$ & $\underline{\text { Lo Ach }}$ \\
\hline \multirow[t]{4}{*}{ Stayers Only } & Lagged Attrition & -0.0336 & $-0.0509 * *$ & 0.0078 & $-0.0373^{*}$ \\
\hline & & $(0.022)$ & $(0.017)$ & $(0.022)$ & $(0.017)$ \\
\hline & Proportion New & 0.0292 & $-0.0778 * * *$ & -0.0043 & $-0.0751 * * *$ \\
\hline & & $(0.022)$ & $(0.018)$ & $(0.024)$ & $(0.019)$ \\
\hline \multirow[t]{4}{*}{ Movers Only } & Lagged Attrition & -0.0821 & 0.0000 & 0.0130 & -0.0776 \\
\hline & & $(0.085)$ & $(0.067)$ & $(0.131)$ & $(0.091)$ \\
\hline & Proportion New & $-0.3023 * *$ & $-0.1207 *$ & -0.1547 & 0.0551 \\
\hline & & $(0.095)$ & $(0.056)$ & $(0.118)$ & $(0.083)$ \\
\hline \multirow[t]{7}{*}{ First Years Only } & Lagged Attrition & 0.0046 & 0.0062 & -0.0537 & $-0.1034 \sim$ \\
\hline & & $(0.045)$ & $(0.046)$ & $(0.060)$ & $(0.059)$ \\
\hline & Proportion New & 0.0079 & 0.0611 & 0.0664 & 0.0164 \\
\hline & & $(0.055)$ & $(0.046)$ & $(0.063)$ & $(0.060)$ \\
\hline & School-by-Year FE & $\mathrm{x}$ & $\mathrm{x}$ & $\mathrm{x}$ & $\mathrm{x}$ \\
\hline & Grade Indicators & $\mathrm{x}$ & $\mathrm{x}$ & $\mathrm{x}$ & $\mathrm{x}$ \\
\hline & Student, School, Class Controls & $\mathrm{x}$ & $\mathrm{x}$ & $\mathrm{x}$ & $\mathrm{x}$ \\
\hline
\end{tabular}




\section{APPENDICES}

\section{Appendix Table 1: Class and School-Level Controls}

\begin{tabular}{lcc}
\hline Class-Level Averages & Mean & SD \\
\hline Class Size & 24.77 & 4.78 \\
Proportion Other Ethnic & 0 & 0.02 \\
Proportion Hispanic & 0.36 & 0.28 \\
Proportion Black & 0.33 & 0.33 \\
Proportion Asian & 0.14 & 0.20 \\
Proportion Home Language English & 0.61 & 0.28 \\
Proportion Free Lunch & 0.61 & 0.30 \\
Lagged Absences & 10.88 & 3.96 \\
Lagged Suspensions & 0.02 & 0.06 \\
Lagged Standardized ELA Scores & 0.1 & 0.60 \\
Lagged Standardized Math Scores & 0.13 & 0.58 \\
Standard Deviation of Lagged ELA Scores & 0.72 & 0.19 \\
Standard Deviation Lagged Math Scores & 0.74 & 0.18 \\
& & \\
School-Level Averages & Mean & SD \\
Enrollment & 834.99 & 324.50 \\
ELL percent & 15.04 & 12.10 \\
Percent Free or Reduced Lunch & 76.24 & 22.27 \\
Percent Black & 30.75 & 30.27 \\
Percent Hispanic & 36.6 & 26.23 \\
Average Expenditure per Pupil & 11090.66 & 2309.30 \\
Age of School & 14.67 & 3.33 \\
\hline
\end{tabular}


